\title{
O espaço da escola na formação continuada de professores: lócus de conquistas ou mera formalidade?
}

\author{
Daniele Rorato Sagrillo* \\ Sueli Menezes Pereira*
}

Clarice Zientarski**

\section{Resumo}

Este trabalho objetiva desenvolver uma reflexão acerca da formação continuada de professores em serviço, tendo como campo de análise uma Escola Municipal de Santa Maria/ RS. Trata-se de um estudo de caso, realizado através de pesquisa documental, e de entrevistas com professores e equipe diretiva. As consideraçóes indicam que o momento de formação continuada de professores da escola investigada fica secundarizado diante de questóes de caráter burocrático, o que limita a autonomia da escola e o seu avanço com vistas à valorização das necessidades emanadas do coletivo. Considera-se que as contradiçóes evidenciadas na formação continuada, como choque de diferentes elementos com interesses antagônicos, podem representar, ao mesmo tempo, aspectos limitadores que subordinam a Educação ao Sistema Capitalista de Produção, mas também impulsionadores de transformaçôes, através da formação, do diálogo, da autonomia, da participação e da leitura crítica.

Palavras-chave: Formação continuada de professores. Participaçáo dos professores. Autonomia da escola.

\footnotetext{
* Doutoranda do Programa de Pós-Graduação em Educação da Universidade Federal de Santa Maria (UFSM).

** Doutora em Educação pela Universidade Estadual de Campinas (UNICAMP). Professora da UFSM, lotada no Departamento de Administração Escolar. Professora do Programa de Pós-Graduação em Educação da UFSM.

*** Doutoranda do Programa de Pós-Graduação em Educação da Universidade Federal de Santa Maria.
} 


\section{Introdução}

Este trabalho é fruto das investigaçóes realizadas pelo Grupo de Pesquisa em Políticas Públicas e Gestão Educacional $\square$ GEPPGE, desenvolvido no Centro de Educação/UFSM, cuja área de abrangência é o Sistema Municipal de Educação de Santa Maria/RS, por meio de sua rede de escolas. Busca identificar a ocupação planejada e sistemática de espaços de formação continuada para professores, a fim de conhecer o processo de construção da autonomia escolar, que se traduz na democracia e na qualidade da educação, através da trajetória de uma das escolas da rede municipal selecionadas como objeto de pesquisa.

Para tanto, vale-se de abordagem qualitativa caracterizada num estudo de caso, considerando que este "[...] não se limita a descrever fatos, acontecimentos ou histórias, mas tenta analisar a interação que existe entre eles, bem como a sua importância no contexto de estudo" (BOGDAN; BIKLEN, 1999, p. 91). Esta investigação, realizada através de pesquisa documental, se reporta aos dados obtidos entre 2008 e 2010. A análise documental teve como referência o Projeto Político-Pedagógico e as Atas de reuniōes da escola em estudo. Além disso, foram entrevistados dez professores, entre eles quatro componentes da equipe diretiva, buscando verificar seu posicionamento quanto à formação continuada que ocorre na escola investigada e, a partir dele, conhecer os espaços de autonomia de que se vale a escola e suas implicaçóes em termos administrativos e político-pedagógicos.

Nessa perspectiva, o presente texto trata da formaçáo continuada de professores no contexto das mudanças propostas pela Legislação Educacional no espaço escolar, o que representa um grande desafio para as instituiçóes educativas, correspondendo ao que preconiza a LDB no 9.394/96, que organiza a educação nacional em todos os níveis e trata, em seu Título VI, Artigo 61, Parágrafo Único, da formação dos profissionais da educação, afirmando que:

A formação dos profissionais da educaçáo, de modo a
atender às especificidades do exercício de suas atividades,
bem como aos objetivos das diferentes etapas e
modalidades da educaçấo básica, terá como fundamentos:
(Incluído pela Lei no 12.014 , de 2009)
I - a presença de sólida formaçáo básica, que propicie
o conhecimento dos fundamentos científicos e sociais 
de suas competências de trabalho; (Incluído pela Lei $\mathrm{n}^{\circ}$ 12.014, de 2009)

II - a associação entre teorias e práticas, mediante estágios supervisionados e capacitaçáo em serviço; (Incluído pela Lei no 12.014 , de 2009)

III - o aproveitamento da formação e experiências anteriores, em instituiçóes de ensino e em outras atividades. (Incluído pela Lei no 12.014 , de 2009) (BRASIL, 1996, grifo nosso).

Ao contemplar a formação continuada de professores como uma das prerrogativas para a melhoria da qualidade da educação, a legislação faz com que ela assuma grande importância no sentido de criar um maior envolvimento dos professores com a gestão da escola, possibilitando avanços em seus aspectos administrativo-pedagógicos. Essas atividades se fazem relevantes para o processo de democratização da gestão e para a construção da autonomia, tendo em vista que é esse o espaço formativo que a instituição escolar tem para decidir e organizar sua proposta pedagógica, para o que deverá contar com a participação da comunidade escolar, descentralizando as decisóes.

Utiliza-se das relaçóes entre educaçáo e trabalho no contexto capitalista como pressuposto de análise, tendo como referência, portanto, as macropolíticas em termos econômicos e sociais, com reflexos diretos na organização escolar. Isso requer conhecer as estratégias da escola para ocupar melhor seu espaço de autonomia na construçáo de uma identidade para a escola pública municipal, de modo que esta assuma seu papel na sociedade.

Para tal construção, faz-se necessária uma análise crítica do papel da escola brasileira no mundo atual, o que torna imprescindível conhecer a problemática que envolve a construçáo da autonomia escolar no contexto do mundo globalizado permeado pelas políticas neoliberais (PEREIRA, 2004). Nessa conjuntura, cabe à escola proporcionar espaços para constante atualização de seus profissionais em serviço, cuja ênfase recaia nas políticas educacionais e nos princípios da gestão em seu caráter administrativo-políticopedagógico. 


\section{Contextualizando a formação continuada em serviço na Educação Básica: entre as macropolíticas e a realidade escolar}

A Educação Básica no Brasil tem se "deteriorado nas últimas décadas" e tende a reduzir-se ao "[...] atendimento [das] necessidades do mercado de trabalho e à lógica empresarial" (FRANCO, 1998, p. 106). Sob essa lógica, ao mesmo tempo em que se observa um retrocesso na educação brasileira em todos os níveis, ela passa a ser definida como estratégica para a dinamização dos processos que visam a contribuir com o desenvolvimento econômico. Dessa forma, o ideário presente, ao "influenciar diretamente as políticas educacionais", acaba por "[...] situar a escola básica como um dever fundamental do Estado e apresenta diferentes formas mediante as quais as empresas podem colaborar com o poder público na educação básica", deliberando, assim, o "[...] tipo de educação demandada das empresas" (FRIGOTTO, 2003, p. 152). Com o processo de reestruturação produtiva e de redefinição do papel do Estado, a Educação Básica passa a ser colocada como patamar mínimo, indispensável para a inserção dos indivíduos no mundo globalizado, em constante mudança.

$\mathrm{O}$ atraso brasileiro quanto à universalização da educação, bem como o fato de esse atraso não ter sido objeto de preocupação nos planos educacionais durante um século (FRIGOTTO, 2003), é um dos indicadores do perfil anacrônico e opaco de nossas elites. Além disso, demonstra um descompasso no discurso da modernidade em termos de defesa da Educação Básica. Quando essa defesa se coloca como objetivo, normalmente os interesses estão voltados não para a maioria da população ou, no caso específico, para a classe trabalhadora. Busca-se estabelecer normas de modo a atender ao "ajuste neoliberal", que precisa do campo educativo para cumprir as demandas da produção. Apontando os órgãos financiadores e definidores das políticas educacionais a serviço do capital, Frigotto (2003, p. 145) afirma:

Os grandes mentores desta veiculaçáo são o Banco Mundial, BID, UNESCO, OIT e os organismos regionais e nacionais a eles vinculados. Por esta trilha podemos perceber que tanto a integraçáo econômica quanto a valorização da educação básica geral para formar trabalhadores com capacidade de abstração, 
polivalentes, flexíveis e criativos ficam subordinados à lógica do mercado.

Ao atenderem as prerrogativas dos interesses internacionais, as reformas educacionais iniciadas nos anos 1990 colocam em grande relevo a formação de professores, tanto inicial como continuada (SHIROMA; MORAES; EVANGELISTA, 2007), uma vez que, paralelamente ao processo de reforma da educação, isso se torna imprescindível para o capital, o que se compreende pela exigência de conhecimentos mais aprimorados em termos científicos e tecnológicos, bem como pelos novos compromissos assumidos pela escola no seu processo de descentralização, como por exemplo: construção coletiva do Projeto-Político-Pedagógico, gerenciamento de recursos financeiros, integração entre escola e comunidade, inclusão digital e social, entre outras tantas tarefas que a escola deverá assumir.

Nessa lógica, Duarte (2004, p. 68), ao tratar da questão na conjuntura atual, salienta o brutal aligeiramento da formação teórica do educador, no qual se instala uma "[...] mentalidade pragmática, centrada no hoje, no aqui e no agora”. Diante disso, Saviani (1997) alerta para a aversão que acaba sendo criada no tocante ao saber "clássico", ou seja, à teoria, colocando-se como importante a valorização do banal, do fácil, do útil, "[...] do que não exija questionamento, crítica e raciocínio” (DUARTE, 2004, p. 68).

Essa situação de precariedade é uma característica do capitalismo atual, para o qual não é mais possível perder tempo com uma formação inicial extensa. O sistema capitalista exige soluçóes rápidas, atendendo ao processo just in time, ou seja, ao melhor aproveitamento possível do tempo de produção no contexto da flexibilização do trabalho (ANTUNES, 1995), o que afeta diretamente a concepção de ensino, porquanto se estabelece uma relação direta do mundo do trabalho com a educação.

Nesse caso, como indica Frigotto (2003), evidencia-se o caráter subordinado das práticas educativas aos interesses do capital que, historicamente, "[...] toma formas e conteúdos diversos, seja no capitalismo nascente, seja no capitalismo monopolista, seja no capitalismo transnacional no contexto da economia globalizada" (FRIGOTTO, 2003, p. 23). Essa realidade não só atinge a formação inicial dos professores, como se reflete também na valorização da formação continuada, com o agravante de essa última não ser priorizada nas escolas, tal como se observou na pesquisa em pauta. 
Isto enfatiza que as relaçóes entre trabalho e educação estão permeadas pela lógica do mercado, que, de uma ou outra forma, tem funcionado como regulador no campo educacional, o que, segundo Frigotto (2003), no Brasil "fez escola". Os efeitos na política educacional, conforme este autor, foram reforçados pela ideologia do regime militar e se expressaram negativamente através dos seguintes fatores: do desmantelamento da escola pública e reforço da educação como negócio; pelo dualismo que criou uma escola para a classe dominante e outra para a classe trabalhadora; assim como pelo tecnicismo e fragmentação que diluiriam o processo de conhecimento. Essas implicações levaram ainda "à proletarização do magistério público", entre outras consequências (FRIGOTTO, 2003, p. 19).

A assertiva dos autores acima citados permite uma aproximação com a escola objeto desta investigação, pois nos documentos norteadores do trabalho $\square$ como o Projeto Político-Pedagógico $\square$ e em Atas de reunióes pedagógicas, assim como nos depoimentos dos professores entrevistados, não há referência a estudos teóricos, concepçóes pedagógicas ou metodológicas que sustentem as práticas desenvolvidas na escola, principalmente no que se refere à formação continuada de professores.

Pimenta (2005) confirma que as propostas governamentais para a formação de professores fundamentam-se, muitas vezes, em conceitos que ficam apenas restritos à retórica e não promovem uma significativa alteração da realidade. Isso gera

[...] políticas de formaçáo contínua [...] fragmentadas [...] acompanhadas de explícitas e às vezes sutis desqualificaçóes das universidades para realizar esta formação, e mesmo da desqualificação e da falta de incentivos para as pesquisas sobre formação de professores que estas têm realizado em escolas públicas, gerando significativo conhecimento sobre as necessidades para as políticas de formação e de desenvolvimento profissional dos professores, das escolas e dos sistemas (PIMENTA, 2005, p. 40-41, grifo do autor).

Tal fato diz respeito também ao compromisso dos Sistemas de Ensino que, ao centralizarem decisóes e não oportunizarem condiçóes adequadas de funcionamento às escolas, acabam prejudicando a busca destas por alternativas 
próprias, evidenciando assim que o discurso da autonomia escolar se insere na lógica do capital.

Mészáros (2004, p. 94) sublinha que o capitalismo, como se apresenta no contexto atual, "é [...] de longe a mais poderosa [...] 'estrutura totalizadora' de controle à qual tudo o mais, inclusive seres humanos, deve se ajustar, e assim provar sua 'viabilidade produtiva', ou perecer, caso não consiga se adaptar'.

Nessa lógica, a formação continuada em serviço tende a servir para treinamento dos professores e adaptação às determinaçóes das reformas educacionais, que depositam na escola um importante papel na manutenção da hegemonia do sistema capitalista de produção. Assim, desloca-se para o indivíduo e para a própria escola a responsabilidade por sua formaçáo e pela realização das ações pedagógicas cotidianas, o que aponta para uma concepção de sucesso individualizante das instituiçôes.

As contradiçóes do sistema são evidentes, visto que o Estado, ao descentralizar o poder, abre espaço para que os professores e sua comunidade se constituam como sujeitos do processo histórico e social, ou seja, ao mesmo tempo em que os professores se inserem nessa lógica, eles possuem a capacidade para contrapô-la, assumindo-se como sujeitos de sua própria formação, através da corresponsabilidade pela construção de um projeto de sociedade que supere e avance as limitaçóes estabelecidas no contexto atual.

É neste cenário que se faz necessária a formação continuada de modo que o professor compreenda criticamente as políticas educacionais, e ocupe os espaços de autonomia e democracia que nelas estáo inseridos, o que implica não só compromissos das instituiçóes formadoras, elevando a formaçáo de professores ao nível superior e garantindo formação continuada, em caráter permanente, mas também açóes e deliberaçóes dos Sistemas de Educação e, principalmente, das próprias escolas.

Assim, entende-se com Kosik (1985, p. 51) ser "[...] o homem, como sujeito histórico real, que no processo social de produção e reprodução cria a base e a superestrutura, forma a realidade social como totalidade de relaçóes sociais, de instituiçóes e ideias". Lukács (1986, p. 2) demonstra isso ao explicitar "[...] que a essência do trabalho humano está no fato de que, em primeiro lugar, ele nasce em meio à luta pela existência e, em segundo lugar, todos os seus estágios sáo produtos da autoatividade do homem". 
Ocupar esses espaços e buscar alternativas de formação que tenham como proposta a construção de uma instituição cidadã não se constitui numa tarefa fácil, tendo em vista que, na realidade concreta das escolas, não se observam modificações significativas, tanto nas instituições responsáveis pela formação inicial e continuada quanto em relação ao comprometimento político dos professores, em sua totalidade, diante dos novos e inúmeros desafios. Essa não é uma situação isolada, considerando-se o fato de pesquisas recentes indicarem que a importância do papel do professor se faz acompanhar, contraditoriamente, de fragmentação e esvaziamento de conteúdo em sua formação (DUARTE, 2003).

Os trabalhos que tratam sobre formação de professores cresceram muito nos últimos anos, e as pesquisas que se referem à formação continuada em serviço, em sua maioria, conforme André et al. (2009), têm como objeto a formação realizada com professores da Educação Básica. Os estudos realizados por Candau (1997), Nóvoa (1991) e Canário (1998), entre outros autores, de uma maneira geral, indicam algumas limitaçóes nos processos de formaçáo continuada, mas sinalizam que ela se apresenta como uma possibilidade para contribuir com avanços no trabalho docente. Nesta perspectiva, pretende-se analisar a escola municipal objeto desta pesquisa.

\section{A formação continuada: um olhar sobre uma escola municipal}

Inserida no contexto das macropolíticas, a escola municipal, como integrante do sistema educacional, encontra-se em face de uma situação conflitante: se, por um lado, perde muitas vezes sua autonomia e capacidade de orientar seus próprios caminhos e espaços formativos ao atender o que está determinado pela política educacional do Estado, por outro, pode contraporse à conjuntura, ao definir uma identidade social, uma proposta coletiva de trabalho e de construçáo do conhecimento.

Ao se analisar o Projeto Político-Pedagógico (PPP), cuja relevância é indiscutível, constatou-se que a formação continuada da escola investigada aparece apenas diluída no texto, às vezes de forma indireta. Não há um item específico que trate da formação dos professores. De acordo com as informaçôes apresentadas nesse documento, cabe à "[...] direção [da escola] oportunizar um constante aperfeiçoamento do corpo docente e da equipe coordenadora" e à "[...] Vice-direçâo promover e participar de reunióes, sessôes 
de estudos, encontros, palestras, seminários e outros" (SANTA MARIA, 2007, p. 20-21).

Assim, percebe-se que a equipe diretiva concentra as açóes relacionadas à formação continuada dos professores, o que é comprovado pelas entrevistas realizadas e atas das reunióes pedagógicas, indicando, como diz Chiavenato (2003, p. 57), que a divisão das funções se reproduz acriticamente na concepção da escola ao colocar na direção e vice-direção funções de decisão isoladas dos professores.

Segundo Lessa (2007, p. 185), essa “[...] é uma forma histórica particular de alienação, aquela que resulta da divisão social do trabalho sob o capital e que, entre outras coisas, opóe 'como inimigos' o 'trabalho manual' e o 'trabalho intelectual' [...]". Nesta perspectiva, com a setorização e a hierarquização, acaba se perdendo a visão global da própria escola, e a formação continuada, que poderia ser um instrumento facilitador de um entendimento maior sobre o contexto e uma reflexão sobre a prática, se perde no vazio.

Neste aspecto, o PPP, por não considerar a história da comunidade escolar e não afirmar fundamentos políticos e filosóficos que promovam mudança, nem tampouco assegurar uma formação fundamentada em processos de vivências democráticas, perde a possibilidade de ser "um meio de engajamento coletivo para integrar açóes dispersas, criar sinergias no sentido de buscar soluçóes, alternativas para diferentes momentos do trabalho pedagógico-administrativo" (VEIGA, 2003, p. 275).

O PPP da escola atua e convive com relações de conhecimento e poder. As regras definidas fora da escola acabam se tornando as regras da escola, através de ações que alteram sua própria dinâmica, sem que o conjunto de professores tenha a oportunidade de discuti-las, analisá-las, compreendê-las e decidir sobre o fazer da escola, demandado pela exigência de suas próprias açóes e também pelas políticas educacionais.

A construção/reconstrução do Projeto Político-Pedagógico é um importante passo a ser dado rumo ao trabalho coletivo, considerando que ele é um elemento da organização da escola em seus múltiplos aspectos: formação continuada, avaliação e currículo, projetos integrados à comunidade, medidas de organização escolar no sentido de atender às diferenças de desempenho de alunos, ocupação dos espaços da escola para atividades pedagógicas e, enfim, avaliação com vistas à função social e política da escola. 
O Plano de Carreira do Magistério Municipal de Santa Maria, instituído pela Lei Municipal no 4.696/2003 (SANTA MARIA, 2003), prevê que a formação continuada aconteça no espaço das horas-atividades, as quais não são destinadas exclusivamente para a formação, por abrangerem também atividades burocrático-pedagógicas inerentes à função. É o que diz a referida lei que trata do plano de carreira:

Art. 22 - Os membros do Magistério que exercerem atividades de regência de classe no Ensino Fundamental, na Educação Profissional, na Educação Infantil, Especial e de Jovens e Adultos deverão ter garantido, no mínimo, $20 \%$ do seu tempo para horas-atividade.

$\$ 11^{\circ}$ - As horas-atividade são reservadas para estudos, planejamento e avaliação do trabalho didático, bem como para atendimento de reuniốes pedagógicas. (SANTA MARIA, 2003).

Observa-se, portanto, que, das 20 horas do regime de trabalho docente, apenas 4 horas são destinadas a outras tarefas de cunho administrativo e pedagógico, entre as quais a formação continuada, o que evidencia o descompasso entre as políticas educacionais municipais e o que preconizam as políticas nacionais, tal como propõe a própria $\mathrm{LDB} / 96$, assim como os organismos internacionais.

Comprova-se, desta forma, na própria legislação municipal a criação de espaço de formaçáo em serviço em uma expressa contradiçáo, pois, ao mesmo tempo em que esse espaço existe legalmente como momento de apropriação e construçáo de conhecimento, ele é insuficiente para atender a tantas tarefas definidas em lei, minimizando a importância do aprofundamento de estudos, da compreensáo crítica da realidade, da possibilidade de, coletivamente, criar alternativas que superem os baixos índices de aprendizagem.

Em acordo com a lei em pauta, na escola municipal em estudo, a limitação dos espaços para a formação é confirmado pelo depoimento das professoras ${ }^{2}$.

Conforme a Professora (V-A) entrevistada, "Na realidade, a gente não tem formação, gurias, é muito burocrático, é muito papel, preencher papel, passar recado. Nós, não, aqui na Escola, nós não temos [formação], dificilmente [...] o tempo é muito curto". Nesta ótica, outra Professora (V-B) demonstra nem se lembrar da última reuniáo pedagógica: "Nós estamos no mês de maio, praticamente, $e$ 
nós tivemos uma formação continuada, esse ano. Se é que teve, ou foi final do ano passado?".

Esses depoimentos indicam que a prioridade das horas-atividades se reduz a reuniôes informativas, mais de caráter técnico-burocrático do que de estudos que diagnostiquem os reais problemas da escola com vistas a um aprofundamento dos referenciais teóricos que deem suporte ao conjunto da comunidade escolar no sentido de buscar alternativas para uma melhoria dos resultados escolares.

A realidade que se evidencia na escola, portanto, confirma um discurso que serve aos interesses do capital, pois as necessidades de construção de uma gestáo democrática para construir coletivamente a identidade da escola se perdem na burocracia, o que não garante a efetividade de uma formação continuada de professores. Neste sentido, de acordo com a Professora VII:

\section{[...] as nossas reuniöes pedagógicas, elas säo... É para ser de estudo, mas a gente faz uma divisão, a gente procura dividir o tempo entre o que tem que ser passado também, os avisos, as organizaçôes, planejamento, que faz parte. Afinal, como é que nós vamos fazer o planejamento dos nossos projetos se não é numa reuniáa pedagógica? Tem que [ ] ali. Depois... A gente faz um projeto, a gente pensa o que fazer, mas ai o que falta, às vezes, é a parte da fundamentação. Eu vejo, a fundamentação fica. E dai, os professores, cada um faz como eles acham que podem e têm condiçôes de fazer, mas dai falta complementar acho que a questão pedagógica, a fundamentação do projeto. Então, tem muitos projetos acontecendo, mas, ao mesmo tempo, falta estudo de cada um de viabilizar isso, fundamentado em autores, em textos, em material.}

Demonstra-se, de fato, que na escola investigada acontece um pequeno espaço para reuniôes pedagógicas, nas quais também acontece a formaçáo continuada. Realizadas normalmente às quartas-feiras, das $10 \mathrm{~h} 15 \mathrm{~min}$ às $11 \mathrm{~h} 45 \mathrm{~min}$ para o turno da manhã, e das $15 \mathrm{~h} 15 \mathrm{~min}$ às $17 \mathrm{~h} 25 \mathrm{~min}$ para o turno da tarde, dia e horário determinados pela Secretaria Municipal de Educação (SMEd) para todas as escolas do município, imposição que prejudica a formação continuada pelos pequenos espaços para tal, assim como compromete a autonomia da escola. Além dessas consideraçóes, a interferência da SMEd 
afeta a participação dos professores que trabalham em mais de uma escola, os quais tendem a não participar ou optar pela participação em uma das escolas onde desempenham suas funçôes, o que implica o alheamento do professor aos problemas das escolas.

Por sua vez, as reunióes de formação continuada têm sido conduzidas de maneira pouco apropriada, considerando que normalmente são tratadas questóes genéricas, ao mesmo tempo em que desperdiçam os períodos em que os professores se encontram na escola, não assegurando sua principal função: propiciar o aprofundamento dos estudos docentes. Isso se torna evidente na fala da Professora III:

[...] em alguns momentos se consegue fazer a leitura de textos (mas não é...) me parece que ainda não é a prioridade da reunião [...]. Isso parece ser um segundo momento, quando surge tempo e deveria ser o contrário. Estar como prioridade, num primeiro momento, e num segundo momento os recados, ou os recados talvez colocar em painéis, ou na sala dos professores em horário de recreio, num outro momento. [...] é um grupo, a gente está ali, é um horário que não pode ser desperdiçado [...]. Tínhamos que no máximo discutir assuntos que nos afligem, que fazem parte do nosso dia a dia e às vezes ficam adormecidos, esquecidos ou ignorados, porque a gente não tem como conversar com outros [...].

A Professora IX, ao mesmo tempo em que reafirma a fala da Professora III, chama a atenção para o fato de que os encontros, além de terem um espaço reduzido de tempo para estudo, se detêm em questóes outras que pouco envolvem aspectos formativos, relacionados a situaçóes concernentes aos alunos e à qualidade da aprendizagem:

[...] a gente está discutindo muito a questão individual do aluno. E o tempo é muito pouco, muito pequeno, se tu fores ver. Tem coisa que tu tens que tratar. Muitas reuniöes acabam tomando muito tempo com avisos, com organização da escola e fica pouco tempo para a formação [...]. (PROFESSORA IX).

A formação continuada, desse ponto de vista, confirma o que já havia sido apontado pelos autores supracitados, tornando-se um processo individual, 
fragmentado, estanque, desvinculado das necessidades vividas no cotidiano escolar, o que a distancia de um processo de democratização da escola, pois não propicia a criação de um coletivo coeso. Afirma-se, com isso, o individualismo liberal sobre a participação coletiva, o que, torna apropriada a afirmação de Marx (2008), ao dizer que:

A produção realizada por um indivíduo isolado, fora do âmbito da sociedade - fato excepcional, mas que pode acontecer, por exemplo, quando um indivíduo civilizado, que potencialmente possui já em si as forças próprias da sociedade, se extravia num lugar deserto - é um absurdo táo grande como a ideia de que a linguagem se pode desenvolver sem a presença de indivíduos que vivam juntos e falem uns com os outros. (MARX, 2008, p. 6 , grifo nosso).

Afirmar a formação continuada dos professores nesse contexto individualizado, no qual as experiências se reduzem a cursinhos de reciclagem, participação em eventos ou ainda, como ocorre na escola investigada, na qual a formação não é priorizada, implica corroborar com o que determina o modelo capitalista. A formação desenvolvida em serviço e não em treinamento é imprescindível, como defende Gadotti (1994). Mesmo assim, essa condição não garante um processo de organizaçáo do trabalho da escola que propicie a melhoria da qualidade do ensino, nem a superação dos problemas demandados do próprio cotidiano.

Nas entrevistas realizadas e na análise do PPP, explicitadas anteriormente, a gestáo da escola é realizada pelas equipes diretivas que concentram as açóes e deliberaçôes, numa expressa contradição ao que se propõe uma gestáo democratizada e participativa, haja vista a divisão do trabalho muito presente na realidade escolar. Isto tem sido preocupação dos professores, o que é demonstrado no comentário:

"[...] não sei como vai ficar no próximo ano, não sei o que vai acontecer aqui na escola, porque [...] é ano de eleiçáo ano que vem, ai eu náo sei qual o rumo que a escola vai adotar. [...] Eu vejo que precisaria haver um trabalho de planejamento maior entre todos, professores e equipe diretiva. Mas também que a equipe diretiva desse esse suporte para os 
professores, para mostrar o que nós queremos, qualé também a nossa proposta. Direcionar, a equipe diretiva faria apenas $o$ direcionamento para que a gente pudesse colocar nossas opinióes [...]. (PROFESSORA VI).

Essa fala demonstra um posicionamento integralmente distanciado de uma proposta coletiva e descentralizada de trabalho, pois há uma equipe que pensa o que o conjunto de professores deve refletir e fazer, o que contradiz a posição de Vasconcellos (2004), ao asseverar que participar das Reunióes Pedagógicas implica se envolver com as discussóes feitas antes, durante e após sua realização. Antes, pelo fato de todos terem de decidir o que será discutido, definir quais as necessidades a serem vistas, trazer os registros desses problemas. Durante, o foco está em acompanhar os relatos, as reflexóes e se envolver com as discussóes, abrir espaço para o envolvimento de todos. Após a reunião, tendo em vista o objetivo buscado, constituir uma direção capaz de orientar a todos (o ponto de partida) e facilitar a concretude do par dialético particular-universal.

Essa posição é referendada por outros estudiosos do assunto, pelo fato de entenderem que os sujeitos, mesmo sendo sociais, náo podem ser objetos de decisóes alheias. Pelo contrário, devem estar envolvidos em todo o processo, pois, segundo Paro (2001, p. 33), “[...] o homem é, antes de tudo, um ser de vontade, um ser que se pronuncia sobre a realidade. Por uma posição de não indiferença com relação ao mundo que o rodeia. [...] o homem cria valores e, a partir deles, estabelece objetivos a serem realizados".

Pergunta-se: como são decididos os assuntos das reunióes de formação? Em que parâmetros se embasa a equipe diretiva para decidir o que é melhor para os professores que conhecem o dia a dia da sala de aula e as características de seus alunos? Como são avaliados o PPP da escola, seus projetos, suas propostas e suas metas, e como os resultados interferem no planejamento da formação continuada dos professores?

Mesmo demonstrando em suas falas possuírem a percepção de que algo está em desajuste, os professores acabam se omitindo e silenciando diante das decisóes hierarquicamente definidas, tanto pela SMEd como pelas equipes diretivas. Neste sentido, a escola é cumpridora das determinaçóes das macro e micropolíticas sem questionar, sem se apropriar do espaço que é concedido pela própria legislação, visto que, sem refletir, apenas aplica em nível micro o que 
já vem definido no espaço macro, situação que se aproxima da apatia política diante da função social da escola.

Novamente, se fortalece a questão da setorização, verticalização e hierarquização presentes na escola, à medida que as reunióes que deveriam ter um caráter formativo, democrático, participativo e decisório acabam se tornando mera formalidade, cumprimento de tarefa e atendimento ao que está definido em nível macro. O que deveriam ser "[...] espaços para que os professores se encontrem, troquem suas vivências, reelaborem suas experiências e tenham retaguarda para implantar seus planos" (ALMEIDA, 2006, p.85) se tornam momentos enfadonhos, desgastantes e inócuos diante das reais necessidades da escola.

Nesta lógica, Libâneo (2001) afirma que as pessoas arrumam tempo para as coisas que compreendem, que valorizam e nas quais acreditam. Contudo, entendemos com Gramsci (1988, p. 107) que

Criar um grupo de intelectuais independentes não é tarefa fácil, exigindo, ao longo do processo, açóes e reaçôes, com adesōes e dissoluçôes, com novas formaçōes muito numerosas e complexas: a concepção de um grupo subalterno, sem iniciativa histórica, que se amplia continuamente, mas de maneira desorgânica e sem poder ultrapassar um certo degrau qualitativo, que está sempre aquém da possessão do Estado, do exercício real da hegemonia sobre toda a sociedade, hegemonia que é a única a permitir um certo equilíbrio orgânico no desenvolvimento do grupo intelectual.

Dessa forma, o trabalho constitui-se numa motivação que não é apenas intrínseca, mas também estimulada pelo meio no qual o sujeito está inserido. Vigotski (1999), baseado em Marx, afirma que mudanças históricas na sociedade e na vida material produzem mudanças na natureza humana, ou seja, no comportamento e na consciência para o que é necessário, como diz Paro (2000), tentar despertar o desejo de mudar em todos por meio de uma crítica ao problema e, desse modo, possibilitar o desequilíbrio, o acordar, o aprofundamento da compreensão, a tomada de consciência da contradição. Possibilita-se, a partir daí, o redirecionamento de perspectiva, proporcionado por alguns subsídios, para orientar concretamente os que querem realmente mudar. 
Rever o Plano de Carreira deverá ser uma luta dos professores junto aos órgãos do Sistema Educacional. Isto requer uma análise das prioridades da escola, garantindo espaços de participação dos professores na gestão de modo a construir um PPP que realmente responda pelas reais necessidades da escola, tendo em vista a melhoria da aprendizagem e a inserção crítica do aluno e do professor num contexto sociopolítico e econômico em constante transformação, o que traz maiores exigências para a instituição escolar. Para tanto, faz-se imprescindível que a comunidade escolar se aproprie dos espaços e assuma a totalidade das açôes de natureza político-pedagógicas da escola. Isso porque, como afirma Cury (2002, p. 172),

[...] a gestão democrática expressa um anseio de crescimento dos indivíduos como cidadáos e do crescimento da sociedade enquanto sociedade democrática [...] [neste caso] a gestáo vai além do estabelecimento e se coloca como um desafio de novas relaçóes [democráticas] de poder entre o Estado, o sistema educacional e os agentes deste sistema nos estabelecimentos de ensino.

Reverter uma lógica centralizadora requer que a comunidade escolar, como alicerce de toda a (re) organização da escola, esteja à frente das decisóes, para o que, necessariamente, se impóe uma formação adequada para o exercício de tal função, compreendendo o PPP da escola como atividade essencial para a integraçáo da comunidade e o estabelecimento de projetos e propostas que respondam por uma melhor qualidade de aprendizagem, tornando a escola uma instituiçấo efetivamente educadora e democrática, o que não acontece na realidade investigada. Nesta ótica, a escola precisa de uma nova organizaçáo administrativo-pedagógica que supere a hierarquização e o centralismo de decisóes.

$\mathrm{Na}$ opiniáo de um dos docentes que compóem a Equipe Diretiva, os colegas em geral demonstram desinteresse pela proposta das reuniôes, afirmando que o comportamento dos professores se assemelha ao "comportamento dos alunos", como demonstra o fragmento a seguir:

Só que eu vejo... Pela participaçâo, a gente tem procurado avaliar, porque, o que a gente tem nas reunióes? Acaba virando conversa e náo se tratando exatamente disso. Ai a 
gente [equipe diretiva] começou a pensar se realmente estava indo ao encontro dos interesses dos professores. [...] A gente está se comportando enquanto aluno, mas a gente tem necessidade de comentar muitas coisas, que sáo as dificuldades que a gente está encontrando diretamente na sala de aula, está sentindo aquilo na pele, o que está te deixando aflita. (MEMBRO DA EQUIPE DIRETIVA II, grifo nosso).

O que chama a atenção neste depoimento é o questionamento desta professora sobre o interesse dos professores pelos assuntos tratados em reunióes, o que sinaliza para uma reflexão sobre a adequação do seu planejamento. É pertinente destacar que a conversa paralela constatada nas reuniôes, efetivamente, pode indicar o desinteresse dos professores com relação ao assunto proposto, já que, pelos dados encontrados na pesquisa, é inexistente sua participação no processo de escolha das temáticas a serem abordadas na formação continuada. Outros espaços de planejamento conjunto deveriam estar contemplados no calendário, de modo que as questóes de ordem administrativo-pedagógicas fossem avaliadas e revistas constantemente, subsidiando-se mais adequadamente a formação continuada.

Tal espaço, se bem aproveitado, seria fundamental para atender minimamente às necessidades da formaçáo, o que não acontece na escola, como reforçam os excertos a seguir, retirados dos depoimentos das Professoras IV e VI, ao se referirem às temáticas desenvolvidas nas reunióes:

Eu acho que ainda não é o suficiente, porque, às vezes [...] alguns assuntos [...] estão distantes das nossas necessidades, são importantes, mas não são as prioridades. Eu penso que talvez também tivessem que ser revistos esses conteúdos, coisas que seriam mais urgentes para o nosso trabalho. (PROFESSORA VI).

Às vezes, tu não tens como trabalhar um tema só numa reunião. Eu acho que tem que explorar mais, trabalhar mais em cima daquele tema e, às vezes, trabalha-se um tema numa reunião, um tema na outra, às vezes, fica meio superficial [...]. Eu náo sei como eles sáo selecionados. Eu acredito que seja um critério da pessoa que, de repente, leu um texto, achou que de acordo com a realidade ou 
com algum momento que está passando a Escola. Eu acredito que seja por aí. (PROFESSORA IV, grifo nosso).

Através desses depoimentos, constata-se que os professores demonstram interesse em que os temas trabalhados estejam mais relacionados às suas realidades e necessidades. Destacamos também que não basta a Equipe Diretiva escolher temas. É preciso que o planejamento das reunióes seja construído coletivamente, tendo como base os problemas do contexto escolar. Somente a partir do diagnóstico de cada situação do processo educativo se tornará possível que as reuniōes ou os espaços de estudos respondam às demandas da escola em sua função educativa, no sentido da transformação social.

Sobre esse aspecto, Fusari (2002, p. 22) afirma que:

[...] qualquer projeto de formação contínua realizado na escola ou em outro local precisa ter assegurado algumas condiçôes. É preciso que os educadores sejam valorizados, respeitados e ouvidos - devem expor suas experiências, ideias e expectativas. É preciso também que o saber advindo de sua experiência seja valorizado; que os projetos identifiquem as teorias e criem situaçóes para que analisem e critiquem suas práticas, reflitam a partir delas, dialoguem com base nos novos fundamentos teóricos, troquem experiências e proponham formas de superação das dificuldades.

Para Frigotto (2003, p. 26) a "educação dos diferentes grupos sociais de trabalhadores deve dar-se a fim de habilitá-los técnica, social e ideologicamente para o trabalho". Dessa forma, a função social da educação perde-se à medida que ela se subordina ao que determina o capital, e isso tem acontecido ao longo da história do capitalismo, que sempre se valeu da educação para seus interesses.

Compreendendo o contexto em que está inserida, a escola tem de ter na formação de professores uma ação permanente que precisa ser repensada de modo contínuo. Ademais, o fato de não possuir um projeto que envolva os professores num processo de mudanças efetivas faz com que a escola fique à mercê de decisóes externas, pois, como afirma Nóvoa (1992, p. 17),

[...] a modernização do sistema educativo passa pela sua descentralização e por um investimento das escolas como 
lugares de formação, na acepção do termo. As escolas têm de adquirir uma grande mobilidade e flexibilidade, incompatível com a inércia burocrática e administrativa que as tem caracterizado. O poder de decisão deve estar mais próximo dos centros de intervenção, responsabilizando, diretamente, os atores educativos.

Ao priorizar a formação em serviço, os professores estabeleceriam uma correlação de forças entre o que está instituído e o que se quer instituir. Ao apropriar-se desse espaço, poderiam ter o efetivo empenho em fazer da escola uma instituição formadora de sujeitos para compreender e compreender-se no contexto em que vivem de modo a nele agir a favor dos interesses sociais.

Desta maneira, no questionamento sobre que mudanças efetivamente deveriam ocorrer, a maioria das respostas salientou o diálogo, o que pode ser comprovado com as falas dos professores:

Fica difícil a integração [...] Eu não conheço teu trabalho, então eu não sei aonde posso me integrar contigo. Então, falta conversar, falta diálogo. Os professores não têm tempo de chegar e sentar. (PROFESSORA V-B).

Diálogo. Tem que ter mais [...] É uma coisa profissional, que a gente tem que pensar na vida do nosso aluno, na nossa profissáo aqui dentro [...] deslanchar o trabalho, mostrar resultado. Então, tem que ter mais abertura, diálogo [...] $\mathrm{A}$ gente sempre vai fazer os cursos, a gente está sempre correndo atrás da máquina. Eu acho que, apesar dessa falta de diálogo $e$ de algum protecionismo, ainda a Escola pode ser séria. (PROFESSORA V-A).

A educação é compromisso com a liberdade e com a transformação da sociedade, e por esta razão fundamenta-se no diálogo. Através do diálogo, se estabelecem uma mediação com o mundo e uma maior significação dos homens como seres humanos. Neste sentido, a educação dialógica se processa no coletivo, pois, como assegura Freire (1981, p. 79): "Ninguém educa ninguém, ninguém se educa a si mesmo, os homens se educam entre si, mediatizados pelo mundo".

O homem é compreendido por Marx (1971) como ser genérico, isto é, como ser que opera sobre o mundo, sobre os outros sujeitos e sobre si mesmo, como gênero, como espécie que busca sua sobrevivência. Contudo, o homem 
não se limita apenas à sobrevivência; ele busca transformar a sociedade e a natureza e sente-se capaz de fazê-lo "[...] porque se reconhece e reconhece ao outro nesse processo" (ANDERY; SÉRIO, 1999, p. 404).

Além disso, no que se refere à educação escolar, não podemos desconsiderar que o homem é um ser histórico, haja vista ser capaz de agir no seu meio, transformando-o. Paro (2001) afirma que ninguém consegue viver sem um sentido maior que sustente a dura luta. Assim, a formaçáo continuada em serviço pode ser um elemento para uma ressignificação do processo de trabalho pedagógico.

A historicidade é a consciência dos processos de construção histórica, dos valores, dos conceitos e das relaçóes dos homens entre si e com a natureza, em que o sujeito como ser histórico diretamente influenciado pela sua época e pelo seu contexto é capaz de constituir-se pelo trabalho consciente (MARX, 1971). Essa relação se dá pela e na práxis (teoria e prática), visto que as condiçóes materiais de vida de uma determinada sociedade determinam nossos pensamentos e, consequentemente, nossa prática social.

Diante do referido contexto, pensar no papel do professor como intelectual implica colocá-lo como sujeito histórico que age sob a influência da situação e do momento que está vivendo, mas que é capaz de provocar mudanças. Por essa razão, é necessário que haja planejamento, desenvolvimento e sistematização de ações que não só busquem o cumprimento de funçôes meramente burocráticas, mas também provoquem a superação e a ruptura definitiva com as práticas evidenciadas.

\section{Considerações finais}

Os resultados preliminares indicam que, apesar de a Lei Municipal de Santa Maria/RS no 4.696/03 (SANTA MARIA, 2003) - que se refere ao Plano de Carreira - determinar um pequeno tempo de horas-atividade, é necessário definir espaços significativos e coletivos para a formação continuada de professores em uma perspectiva gramsciana da formaçáo do intelectual de modo que a escola valorize seus profissionais em busca de uma melhor qualidade de ensino, o que se torna imprescindível para reverter o atual quadro de tal formaçáo: superficial e inadequada às reais necessidades da instituição.

A formação realizada na escola investigada reúne, na maioria das vezes, o trato de assuntos de caráter diverso, tais como: questóes organizacionais, 
informes, recados da Secretaria Municipal de Educação (SMEd) - a respeito de prazos a serem cumpridos -, eventos, queixas de professores sobre alunos, relatos pela Orientadora Educacional sobre os alunos considerados "problema", entre outros. Isso se dá sem que uma análise das causas seja realizada ou que propostas de soluções coletivas sejam planejadas, evidenciando que, ao tratar de tantos assuntos num pequeno espaço de tempo, a formaçáo continuada é, praticamente, negligenciada.

Confirma-se, assim, que a formação continuada, nessa perspectiva, fica secundarizada diante das questóes burocráticas e organizacionais, o que restringe a escola a decisóes do imediato, sem que avance em propostas práticas, com vistas à valorização das necessidades emanadas do coletivo. Há ainda o agravante de as deliberaçôes sobre a formação continuada concentrarem-se na equipe diretiva, o que impede a descentralização de ações, o trabalho coletivo e, naturalmente, o crescimento dos professores como profissionais comprometidos com o processo de transformação social da escola.

Dessa forma, ao corroborar as determinaçóes impostas, os professores estariam coniventes com a lógica reprodutivista, haja vista apenas concordarem - e pactuarem - com o que foi resolvido pelo grupo que "pensa" a escola. Nesse caso, os conservadores

[...] não apenas dominaram o debate acerca da natureza e dos propósitos da escola pública como também têm cada vez mais determinado o termo em torno dos quais as recomendaçóes políticas têm sido desenvolvidas e implementadas em níveis local e nacional. (GIROUX, 1997, p. 27).

Gramsci (1988, p. 8-9) assinala que a escola é o "instrumento para elaborar os intelectuais". Observa-se, no entanto, que muitas vezes, tanto a escola quanto seus professores, à disposiçấo do Estado para o exercício da função hegemônica, cumprem papéis burocráticos distantes da função social da escola. No desenvolvimento de seu trabalho, acabam executando as ordens do próprio sistema e não tomam nenhuma iniciativa autônoma na construção do projeto político-pedagógico da escola nem na realização do trabalho ou do processo formativo. Em tal perspectiva, se 
[...] no aparato produtivo industrial, a alta intelectualidade está identificada com o estado-maior industrial enquanto a massa de intelectuais assemelha-se aos oficiais subalternos, náo elabora os planos de construção, limitando-se a controlar suas fases executivas complementares (GRAMSCI, 1988, p. 12).

Esse é um fator significativo da tradição paternalista de nossa sociedade que, associada a uma formação para "o fazer e o cumprir", coloca o professor como um elemento acrítico e distanciado de qualquer discussão que possibilite alteraçôes significativas na realidade escolar (PEREIRA, 2004). Tais aspectos se apresentam no âmbito da escola municipal investigada e se constituem em fatores impeditivos da construçáo do coletivo escolar, prejudicando fundamentalmente o requisito mais avançado da Lei no 9.394/96 (BRASIL, 1996), que é o princípio da democratização, visto que as tentativas de mudança nas escolas são frutos de decisôes isoladas e centralizadas, reproduzindo e legitimando a ideologia capitalista.

Com isso, assume-se o risco de a escola ser devorada pelo urgente, não tendo tempo de se posicionar sobre o importante (GADOTTI, 1999), ou seja, a construção ou fortalecimento de uma educação para além do capital (MÉSZÁROS, 2005). Afastar esse risco exige uma proposta de formação do professor que o distancie da setorização, do tecnicismo, da burocratizaçáo e da reproduçáo do conhecimento.

Tal ação constitui-se no motivo que poderá provocar mudanças no projeto pedagógico, impulsionando a tomada de decisóes próprias que marquem a existência de uma escola efetivamente autônoma, conhecedora da importância de seu papel na sociedade a partir de seus professores. Assumindo essa perspectiva, a escola não ficará apenas repetindo em nível micro o que foi estabelecido em nível macro, nem tentará resolver problemas imediatos, tais como questôes disciplinares, dificuldades individuais de aprendizagem isoladas do contexto social, problemas individuais de professores, problemas internos de organização, entre outros.

Quando a escola passa a pensar a formação como instrumento para se contrapor à organizaçáo setorizada-hierarquizada da sociedade capitalista, liberta-se de tais "amarras" e compreende o sentido social e político do processo formativo. As contradiçóes evidenciadas na (de)formação continuada, como 
choque de diferentes elementos com interesses antagônicos, podem representar, ao mesmo tempo, aspectos limitadores, que subordinam a Educação ao Sistema Capitalista de Produção, mas também impulsionadores de transformaçôes, através da formação, do diálogo, da autonomia, da participação e da leitura crítica. São, portanto, essas contradições contidas nos fenômenos, seus elementos antagônicos e o seu movimento que levam a soluções/saídas - à negação da negação (MARX, 1971). Adotando essa postura, as escolas estariam se reconcebendo como esferas públicas democráticas, nas quais alunos e professores trabalhariam juntos para "[...] forjar uma nova visão emancipadora da comunidade e da sociedade" (GIROUX, 1997, p. 31).

Negar o processo de formação continuada de professores, tal como está sendo realizado, implica propor alternativas que tirem esses profissionais da condição de meros expectadores apáticos e os coloquem na condiçáo de seres pensantes e atuantes no processo de construçáo de uma educaçáo comprometida com a transformação social.

\section{Notas}

1 Ao transcrever as entrevistas dos professores, procurou-se manter as marcas típicas da fala. Os dados referentes a esta pesquisa encontram-se disponíveis para consulta na íntegra.

\section{REFERÊNCIAS}

ALMEIDA, Laurinda Ramalho de. A dimensão relacional no processo de formação docente: uma abordagem possível. In: BRUNO, Eliane B. Gorgueira; ALMEIDA, Laurinda R. de; CHRISTOV, Luiza Helena da Silva (Org.). O coordenador pedagógico e a formação docente. São Paulo: Loyola, 2006.

ANDERY, Maria Amália; SÉRIO, Teresa Maria. A prática, a história e a construção do conhecimento: Karl Marx (1818-1883). In: ANDERY, Maria Amália et al. Para compreender a ciência: uma perspectiva histórica. São Paulo: EDUC/Espaço e Tempo, 1999. p. 395-425.

ANDRÉ, Marli et al.. Estado da Arte da Formação de Professores no Brasil. Educação \& Sociedade, Campinas, ano XX, n. 68, p. 301-309. Dez. 1999. 
Disponível em: <http://www.scielo.br/pdf/es/v20n68/a15v2068.pdf>. Acesso em: 20 mar. 2012.

ANTUNES, Ricardo. Adeus ao trabalho? Ensaio sobre as metamorfoses e a centralidade do mundo do trabalho. Sáo Paulo: Cortez, 1995.

BRASIL. Ministério da Educação. Lei no 9.394/96, de 20 de dezembro de 1996. Estabelece as diretrizes e bases da educação nacional. Diário Oficial da União. Brasília, DF, 23 dez. 1996. Disponível em: <www.planalto.gov.br/ ccivil_03/Leis/L9394.htm>. Acesso em: 21 out. 2009.

BOGDAN, Robert; BIKLEN, Sari. Investigação Qualitativa em Educação: uma Introdução à teoria e aos métodos. Porto: Porto Editora, 1999.

CANÁRIO, Rui. A escola, o lugar onde os professores aprendem. Psicologia da Educação. São Paulo, n. 6, p. 9-28, 1998.

CANDAU, Vera Maria (Org.). Magistério: construção cotidiana. Petrópolis, RJ: Vozes, 1997. p. 51-68.

CHIAVENATO, Idalberto. Introdução à Teoria Geral da Administração. 7. ed. Rio de Janeiro: Elsevier, 2003.

FRANCO, Maria Ciavatta. Mediaçóes históricas de trabalho e educação. Rio de Janeiro: Lamparina, 1998.

CURY, Carlos Jamil. Gestão democrática da educação: exigências e desafios. Revista Brasileira de Política e Administração da Educação, São Bernardo do Campo, v. 18, n. 2, p. 163-174, jul./dez. 2002.

DUARTE, Newton. Sociedade do conhecimento ou sociedade das ilusôes? Quatro ensaios crítico-dialético em Filosofia da Educação. Campinas: Autores Associados, 2003.

DUARTE, Newton. Vigotski e o aprender a aprender: crítica às apropriações neoliberais e pós- modernas da teoria vigotskiana. Campinas: Autores Associados, 2004.

FUSARI, José Cerchi. Formação contínua de educadores na escola e em outras situações. In: BRUNO, Eliane Bambini G. (Org.). O coordenador pedagógico e a formação docente. Sáo Paulo: Loyola, 2002.

FREIRE, Paulo. Pedagogia do Oprimido. 9. ed. Rio de Janeiro. Editora Paz e Terra, 1981. 
FRIGOTTO, Gaudêncio. Educação e crise do capitalismo real. São Paulo: Cortez, 2003.

GADOTTI, Moacir. Organizaçâo do trabalho na escola: alguns pressupostos. São Paulo: Ática, 1994.

GIROUX, Henry A. Os professores como intelectuais: rumo a uma pedagogia crítica da aprendizagem. Porto Alegre: Artes Médicas, 1997.

GRAMSCI, Antonio. Os intelectuais e a organização da cultura. Rio de Janeiro: Civilização Brasileira, 1988.

LIBÂNEO, José Carlos. Organização e gestão da escola: teoria e prática. Goiânia: Alternativa, 2001.

LESSA, Sérgio. Trabalho e proletariado no capitalismo contemporâneo. São Paulo: Cortez, 2007.

LUKÁCS, Georg. Ontologia do ser social. Tradução de Ivo Tonet. Maceió, AL, 1986. Disponível em: <ttp://afoiceeomartelo.com.br/posfsa/Autores/ Lukacs, \%20Georg/O\%20TRABALHO\%20-\%20traducao\%20revisada. pdf>. Acesso em: 15 jan. 2012.

KOZIK, Karel. Dialética do concreto. Rio de Janeiro: Paz e Terra, 1985.

MARX, Karl. O capital: crítica da economia política. Rio de Janeiro: Civilização Brasileira, 1971. Livro 1. v. 1.

MARX, Karl. Contribuição à crítica da economia política. São Paulo: Expressão Popular, 2008.

MÉSZÁROS István. O poder da ideologia. São Paulo: Boitempo, 2004.

MÉSZÁROS István. A educação para além do capital. São Paulo: Boitempo, 2005.

NÓVOA, António. As organizaçôes escolares em análise. Lisboa: D. Quixote, 1992.

NÓVOA, António. Concepções e práticas de formação contínua de professores. Formação contínua de professores: realidades e perspectivas. Portugal: Universidade de Aveiro, 1991.

PARO, Vitor. H. Reprovação escolar: renúncia à educação. São Paulo: Xamã, 2000. 
PARO, Vitor. H. Gestão democrática da escola pública. São Paulo: Ática, 2001.

PEREIRA, Sueli Menezes. Educação continuada: um imperativo aos profissionais da educação diante das políticas educacionais atuais. Revista Poiésis, Cataláo, v. 2, n. 2, p. 25-38, jan./dez. 2004.

PIMENTA, Selma Garrido. Professor reflexivo: construindo uma crítica. In: PIMENTA, Selma Garrido; GHEDIN, Evandro. (Org.). Professor reflexivo no Brasil: gênese e crítica de um conceito. São Paulo: Cortez, 2005.

SANTA MARIA. Lei Municipal no 4.696/03, de 22 de setembro de 2003. Estabelece o Plano de Carreira do Magistério Público Municipal, Institui o respectivo Quadro de Cargos e dá outras providências. Santa Maria, RS, 22 set. 2003. Disponível em: <http://www.santamaria.rs.gov.br/docs/ Pub_23080226-66.pdf>. Acesso em: 29 jul. 2011.

SANTA MARIA. Projeto Político-Pedagógico: Escola da Rede Municipal de Ensino de Santa Maria. Santa Maria, RS, 2010.

SAVIANI, Demerval. Escola e democracia. Campinas: Autores Associados, 1997. (Polêmicas do Nosso Tempo, v. 5).

SHIROMA, Eneida; MORAES, Maria Célia Marcondes; EVANGELISTA, Olinda. Política Educacional. Rio de Janeiro: Lamparina, 2007.

VASCONCELLOS, Celso dos Santos. Avaliação: concepção dialéticalibertadora do processo de avaliação escolar. São Paulo: Libertad, 2004.

VEIGA, Ilma Passos Alencastro.Inovações e projeto político-pedagógico: uma relação regulatória ou emancipatória? Cadernos CEDES, Campinas, SP, v. 23, n. 61, p. 267-281, dez. 2003. Disponível em: <http://www.scielo.br/ pdf/ccedes/v23n61/a02v2361.pdf>. Acesso em: 15 jan. 2012.

VIGOTSKI, Lev. Semenovick. A formação social da mente: o desenvolvimento dos processos psicológicos superiores. São Paulo: Martins Fontes, 1999. 


\section{EI espacio de escuela en educación continua de profesores: locus de conquista o mera formalidad?}

\section{Resumen}

Este trabajo tiene como objetivo desarrollar una reflexión sobre la educación continua de los profesores en servicio, con el campo del análisis de una Escuela Municipal de Santa Maria/RS. Este es un caso de estudio, llevado a cabo a través de investigación documental y entrevistas con profesores y equipo directivo. Las consideraciones indican que el momento para la educación continua de los profesores de la escuela investigada es dejado de lado ante las cuestiones de carácter burocrático, lo que limita la autonomía de la escuela y su progreso con miras a la valoración de las necesidades que emanan de la colectividad. Se considera que las contradicciones evidentes en la educación continua, como un choque de diferentes elementos que tengan intereses contrarios, pueden representar, al mismo tiempo, aspectos limitantes que hacen que la educación sea subordinada al Sistema Capitalista de Producción, pero también los impulsores del cambio a través de la capacitación, el diálogo, la autonomía, la participación y la lectura crítica.

Palabras claves: Educación Continua de los profesores. Participación de los profesores. Autonomía de la escuela.

\section{School space in the continuing education of teachers: locus of conquests or mere formality?}

\section{Abstract}

This study reflects on the continuing education of working teachers, with the field of analysis a municipal school in Santa Maria, Rio Grande do Sul State. This is a case study, conducted with document research and interviews with teachers and administrators. Their statements indicate that the allocation of time for the continued education of the school teachers studied is given secondary importance to bureaucratic issues, which limits the autonomy of the school and its advances in meeting collective needs. The contradictions identified in continuing education, which result from conflicting interests, can simultaneously represent limiting aspects that subordinate education to the system of capitalist production. But they are also stimulants of transformations, because they encourage dialog, autonomy, participation and critical reading.

Keywords: Continuing teacher education. Participation of teachers. School Autonomy. 


\section{Daniele Rorato Sagrillo}

E-mail: danielesagrillo@yahoo.com.br

\section{Sueli Menezes Pereira}

E-mail: sueli@ce.ufsm.br

\section{Clarice Zientarski}

E-mail: claricezientarski@yahoo.com.br

Recebido em: 1/2/2012

Versão final recebida em: 8/10/2012

Aprovado em: 8/11/2012 